\title{
A RETROSPECTIVE ANALYSIS OF FIREARMS INJURIES DURING THE PERIOD FROM 2016 TO 2019 IN FAYOUM GOVERNORATE, EGYPT.
}

\author{
Marwa A Mwaheb ${ }^{1}$ Heba H Rohym ${ }^{2}$ \\ ${ }^{1}$-Assistant Professor Department of Forensic Medicine and Clinical Toxicology, ${ }^{2}$-Lecturer \\ Department of Forensic Medicine and Clinical Toxicology, Fayoum University, Egypt
}

\begin{abstract}
Background: Firearm related injuries continue to increase throughout the world and become the first or second cause of mortality worldwide. The present study aimed to determine factors that affect mortality in firearm injuries. Methods: A retrospective review was conducted on data obtained from 100 firearm injured patients who were recorded to Forensic Medical Authority in Fayoum Governorate, between January 2016 and October 2019. Results: This research shows slight increase of firearm injuries. In years 2016 and 2017, they recorded to be 22 cases (22\%) while in year 2018, firearm injuries were 27 cases $(27 \%)$ and in year 2019, firearm injuries were 28 cases $(28 \%)$. The study revealed that firearm injuries were more common in males than females. There percentages were $91.0 \%, 91.3 \%$, $85.19 \%$ and $78.57 \%$ in years 2016, 2017, 2018 and 2019 respectively. This research recorded that, firearm injuries were more common in the age group between (20-40) years they included 60 males $(86.96 \%)$ and 9 females $(13.04 \%)$. This study revealed that, rural areas were the main place for firearm injuries. In 2016, 14 cases $(63.64 \%)$ were from rural areas while 8 cases $(36.36 \%)$ were from urban. In 2017, 17 cases $(73.91 \%)$ were from rural but 6 cases $(26.08 \%)$ were in urban. In 2018, 21 cases $(77.77 .3 \%)$ were from rural but 6 cases $(22.23 \%)$ were from urban. In 2019, 20 cases $(71.42 \%)$ were from rural but 8 cases $(28.58 \%)$ were in urban. female and male victims of firearm injuries were mainly in rural places. The study revealed that most of firearm injured cases were accidental in year 2016. In year 2017, 2018, 2019 cases were mainly homicidal. Conclusion: Our research proved that during the period of 2016-2019, there was a slight increase of firearm injuries mostly homicidal male victims in rural area. Limbs were the main sites of injuries. The slight non-significant increase of firearm injuries found in this study, reflects the current tight weapon law guidelines in Egypt.
\end{abstract}

Keywords: Firearm injuries, Firearm forensic aspect, Egypt.

\section{INTRODUCTION}

Gun wounds are regular all through the world, particularly after the gun business showed incredible advances during the second half of the nineteenth century. Such wounds may cause high morbidity and mortality because of going with organ and vessel injuries (Iflazoglu N, Ureyen O, Oner OZ et al., 2015) (Saly Y Abdel- Hameed,Ahmed K Ibrahim, Hayam $\mathrm{Z}$ thabet and Aml A Mohamed, 2017), Since the shot is quick, has dangerous properties and turns while propelling, it can harm the organs and the encompassing tissues that it goes through. Moreover, it might alter course in the body and go to a few distinct areas from the purpose of passageway. Hence, gun wounds could cause more harm than foreseen (Karaca, Kartal, Erbil et al., 2015), (KasımTurgut, Ali Gür, TanerGüven, and HakanOğuztürk, 2019).

All through the world passings because of gun weapons have expanded colossally. In Egypt, yearly passings coming about because of guns all out 2011: 1388, however in 2000:157. In Egypt, the yearly pace of all weapon passings per 100,000 populace is 2011: 1.7 yet in 2000: 0.24 (Abdel-Hady, Abdel-Moneim and Abdel-Aal, 2012)) While The wounds 
compressed air firearms cause might be viewed as pointless from the outset, they may include major inside tissue pathologies. These apparently wounds may have appalling outcomes if unnoticed. These machines are not guiltless. In Egypt some unintentional gun wounds and fatalities were accounted for in rustic regions, because of the utilization of compressed air firearms in weddings, occasions and celebrations (Lustenberger T, Inaba K, Schnüriger B, et al., 2011), (Aboelyazid Foud, Ahmed Mousa et al, 2019). The severity of firearms injuries is determined by two factors: The damage of the tissues caused by the mechanical interaction between the bullet and the tissues, and the effects of the temporary cavity produced by the bullet. The medical, legal, and emotional costs of this violence impose an enormous burden on urban and rural trauma hospitals, and the courts, families, and society. The valuation of these injuries needed to specialized training and expertise, whether by an emergency physician in a living gunshot victim or a forensic pathologist in the deceased. There is growing concern about the indiscriminate use of firearms on a large scale, particularly in the last decade. The availability of firearms known as small arms and light weapons (SALW) has been described as a cancer spreading across the developing world. It destabilizes political, social, and economic systems, and leads to injury, death, and chaos (Humayun, Khan, Zaman, et al., 2009), (Al Madni and Kharosha, A., 2008).

This study aimed to determine the factors that affect mortality due to firearm related injuries by evaluating injury characteristics, demographics of victim, the incidence and pattern of firearm injuries and deaths in Fayoum Governorate.

\section{METHODS}

A retrospective review was conducted on data obtained from 100 patients who were recorded to Forensic Medical Authority in Fayoum Governorate of firearm injuries, between January 2016 and October 2019. All firearm death records were thoroughly reviewed for the following information: Demographic data of the victim, including, age, sex, residence, and occupation. The manner of death (accidental, suicidal, homicidal) and the date of the accident.

\section{Statistical Analysis}

- Data were gathered and coded to facilitate data processing; then they were double entered into Microsoft Access and were then processed using SPSS software version 18 under windows 7.

- A simple descriptive analysis in the form of numbers and percentages for qualitative data, and arithmetic means as a central tendency measurement, standard deviations were used as a measure of dispersion for quantitative parametric data, and inferential statistic test.

\section{RESULTS}

This research shows that there is slight increase in firearm injuries even it is nonsignificant increase in the last four years. In year 2016,22 cases (22\%) were recorded ,in year 2017 ,firearm injuries were 23 cases $(23 \%)$, in year 2018, firearm injuries were 27 cases $(27 \%)$ and in year 2019, firearm injuries were 28 cases( $28 \%)$ as shown in table (1).

Table (2) and fig. (1) show that, In year 2016 firearm injuries were more common in males (91.0\% of cases) than in females $(9,00 \%)$. In $2017,91.3 \%$ of cases were males while $8.7 \%$ of cases were females. In 2018, $85.19 \%$ of cases were males in comparison to $14.81 \%$ of female case. In $2019,78.57 \%$ of cases were males and $21.42 \%$ were females. This research recorded that firearm injuries were more common in age group between (20-40) years, they were 60 males $(86.96 \%)$ and 9 females $(13.04 \%)$ as shown in table 3 . Rural areas were the main place for firearm injuries. In 2016, 14 cases $(63.64 \%)$ were from rural areas while 8 cases $(36.36 \%)$ were from urban. In 2017, 17cases $(73.91 \%)$ were from rural areas but 6 cases $(26.09 \%)$ were from urban. In 2018, 21 
cases $(77.7 \%)$ came from rural areas and 6 cases $(22.23 \%)$ were from urban. In 2019, 20 cases $(71.42 \%)$ were from rural areas but 8 cases $(28.58 \%)$ were from urban as shown in table 4 . female and male victims of firearm injuries were mainly in rural places as show in fig. (2).

This study recorded no statistically significant difference between fatality and cases of firearm injuries. Most of the cases of firearm injures in this study were nonfatal, only 2 fatal cases were recorded in years 2018 and 2019,while in years 2016 and 2017 all firearm injuries were nonfatal (23 cases $(100 \%)$ in each year) In year 2018,26 non-fatal cases $(96.3 \%)$ were recorded, while in year 2019,27 non-fatal cases $(96.40 \%)$ were found as shown in table (5). The study revealed that limbs were the most common sits of firearm injuries. In year 2016 there was only one case $(4.50 \%)$ of firearm injuries in head and neck, 15 cases (68.18) of firearm injuries in limbs, 4 cases $(18.00 \%)$ in trunk and 2 cases (9.00) in more than on site in the same victim. In year 2017 there was 2 cases $(8.70 \%)$ in head and neck, 13cases (56.50) in limbs, 2 cases $(13.50 \%)$ in trunk and 5 cases(21.30) in more than on site in the same victim. in year 2018 there were 3 cases $(11.10 \%)$ of firearm injuries in head and neck, 14 cases (51.90) in limbs,3 cases $(11.10 \%)$ in trunk and 7 cases (25.90) in more than on site in the same victim. in year 2019 there was 7 firearm injured cases $(25.00 \%)$ in head and neck, 14 cases (50.00) in limbs, 3 cases $(7.30 \%)$ in trunk and 5 cases (17.80) in more than on site in the same victim as shown in table(6). The study revealed that most of firearm injured cases were accidental in year 2016. In year 2017, 2018, 2019 cases were mainly homicidal as shown in fig. (3)

Table (1): Distribution of the victims according to years of the study.

\begin{tabular}{|l|l|l|l|}
\hline \multirow{2}{*}{} & \multicolumn{2}{|c|}{ P-value } \\
\cline { 2 - 3 } & $\mathrm{N}$ & $\%$ & \\
\hline 2016 & 22 & $22 \%$ & \multirow{3}{*}{0.436} \\
\hline 2017 & 23 & $23 \%$ & \multirow{2}{*}{0.43} \\
\hline 2018 & 27 & $27 \%$ & \\
\hline 2019 & 28 & $28 \%$ & \\
\hline
\end{tabular}

*P<0.05: statistically significant $\mathbf{p}>0.05=$ statistically non-significant

Table (2): Relation between sex and year of firearm injuries.

\begin{tabular}{|c|c|c|c|c|c|}
\hline & \multicolumn{2}{|c|}{ female } & \multicolumn{2}{|c|}{ male } & \multirow[t]{2}{*}{ P-value } \\
\hline & $\mathrm{N}$ & $\%$ & $\mathrm{~N}$ & $\%$ & \\
\hline 2016 & 1 & $8.69 \%$ & 21 & $91.30 \%$ & \multirow{4}{*}{0.257} \\
\hline 2017 & 2 & $8.69 \%$ & 21 & $91.30 \%$ & \\
\hline 2018 & 4 & $14.81 \%$ & 23 & $85.19 \%$ & \\
\hline 2019 & 6 & $21.42 \%$ & 22 & $78.57 \%$ & \\
\hline
\end{tabular}




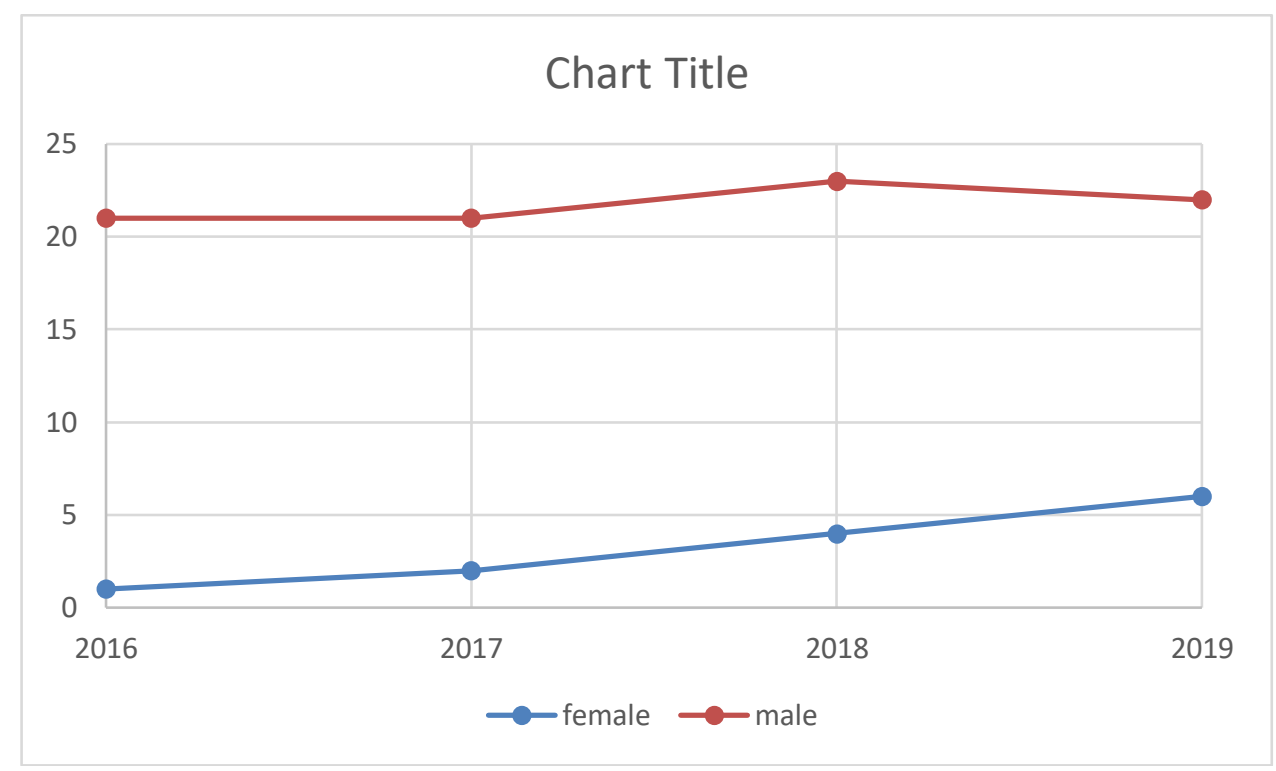

Figure (1): Relation between sex and year of firearm injuries

Table (3): Relation between age and gender among victims of firearm injuries in Fayoum Governorate during the period from 2016 to 2019.

\begin{tabular}{|l|l|l|l|l|}
\hline & \multicolumn{2}{|l|}{ female } & \multicolumn{2}{l|}{ male } \\
\cline { 2 - 5 } & $\mathrm{N}$ & $\%$ & $\mathrm{~N}$ & $\%$ \\
\hline $\begin{array}{l}\text { Less } \\
\text { than 20 }\end{array}$ & 2 & $25.30 \%$ & 6 & $75.00 \%$ \\
\hline $20-40$ & 9 & $13.04 \%$ & 60 & $86.96 \%$ \\
\hline $\begin{array}{l}\text { More } \\
\text { than 40 }\end{array}$ & 2 & $8.69 \%$ & 21 & $91.31 \%$ \\
\hline
\end{tabular}

Table (4): Relation between residence and year of firearm injuries.

\begin{tabular}{|l|l|l|l|l|l|}
\hline \multirow{2}{*}{} & rural & urban & \multirow{2}{*}{ P-value } \\
\cline { 2 - 5 } & $\mathrm{N}$ & $\%$ & $\mathrm{~N}$ & $\%$ & \\
\hline 2016 & 14 & $63.64 \%$ & 8 & $36.36 \%$ & \multirow{2}{*}{0.195} \\
\hline 2017 & 17 & $73.91 \%$ & 6 & $26.08 \%$ & \\
\hline 2018 & 21 & $77.77 \%$ & 6 & $22.23 \%$ & \\
\hline 2019 & 20 & $71.42 \%$ & 8 & $28.58 \%$ & \\
\hline
\end{tabular}

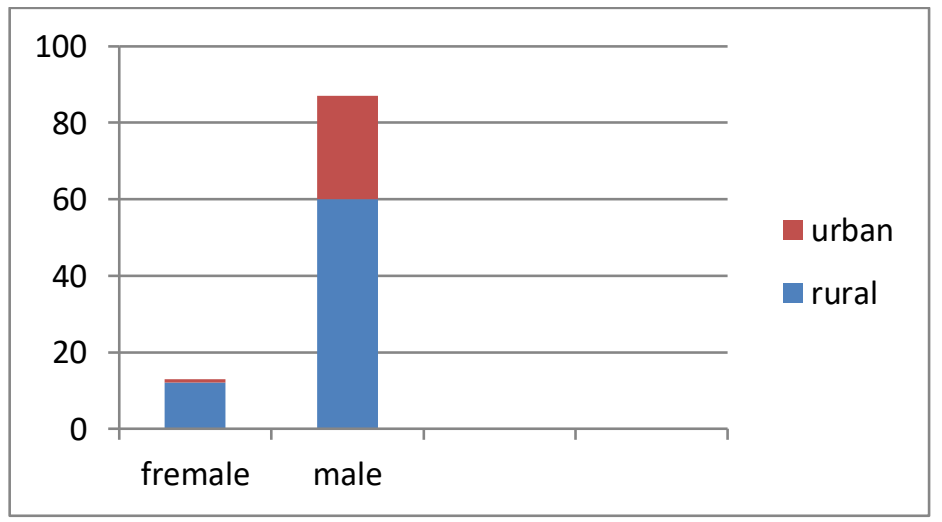

Figure (2): Relation between residence and sex in firearm injuries 
Table (5): Distribution of mortality rate of firearm injuries according to years

\begin{tabular}{|l|l|l|l|l|l|}
\hline & \multicolumn{2}{|l|}{ fatal } & \multicolumn{2}{l|}{ Non-fatal } & \multirow{2}{*}{ P-value } \\
\cline { 2 - 5 } & $\mathrm{N}$ & $\%$ & $\mathrm{~N}$ & $\%$ & \\
\hline 2016 & 0 & $0.00 \%$ & 23 & $100.00 \%$ & \multirow{2}{*}{0.297} \\
\hline 2017 & 0 & $0.00 \%$ & 23 & $100.00 \%$ & \\
\hline 2018 & 1 & $3.70 \%$ & 26 & $96.30 \%$ & \\
\hline 2019 & 1 & $3.60 \%$ & 27 & $96.40 \%$ & \\
\hline
\end{tabular}

Table (6): Relation between site and year of accidents in firearm injuries

\begin{tabular}{|c|c|c|c|c|c|c|c|c|c|}
\hline & \multicolumn{2}{|c|}{ head and neck } & \multicolumn{2}{|c|}{$\operatorname{limbs}$} & \multicolumn{2}{|c|}{$\begin{array}{c}\begin{array}{c}\text { more than one } \\
\text { sites }\end{array} \\
\end{array}$} & \multicolumn{2}{|c|}{ trunk } & \multirow{2}{*}{ P-value } \\
\hline & $\mathbf{N}$ & $\%$ & $\mathbf{N}$ & $\%$ & $\mathbf{N}$ & $\%$ & $\mathbf{N}$ & $\%$ & \\
\hline 2016 & 1 & $4.50 \%$ & 15 & $68.18 \%$ & 2 & $9.00 \%$ & 4 & $18.0 \%$ & \multirow{4}{*}{0.210} \\
\hline 2017 & 2 & $8.70 \%$ & 13 & $56.52 \%$ & 5 & $21.70 \%$ & 3 & $13.00 \%$ & \\
\hline 2018 & 3 & $11.10 \%$ & 14 & $51.90 \%$ & 7 & $25.90 \%$ & 3 & $11.10 \%$ & \\
\hline 2019 & 7 & $25.00 \%$ & 14 & $50.00 \%$ & 3 & $7.20 \%$ & 5 & $17.80 \%$ & \\
\hline
\end{tabular}

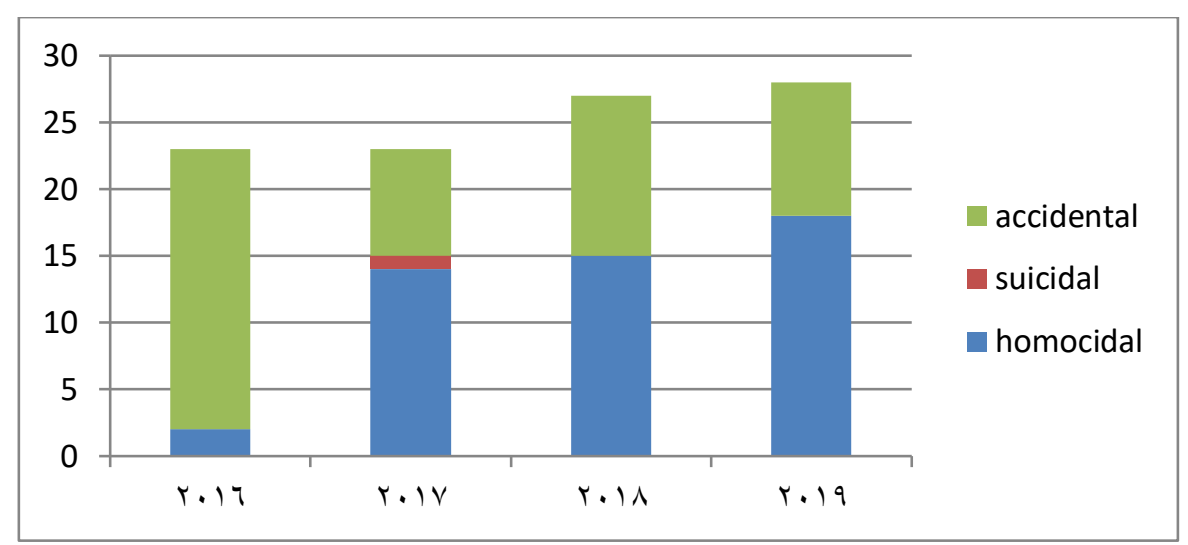

Figure (3): Relation between mode and years of firearm injuries

\section{DISCUSSION}

A populace in various nations, paying little heed to their main land area, have different accessibility to procure guns, which mirror the quantity of gun related passings and impairing injuries (Anthony M, Nasser AAlAqil1, Nawaf A AlOkeil, et al., 2019) Injuries from guns are a significant medical issue that seriously influences the criminal equity and medicinal services frameworks. Such wounds are regular in Egypt. In spite of the size of this issue, little is thought about the epidemiologic qualities of these injuries (Humayun M, Khan D, Zaman F, Khan J, et al., 2009): The current study is a retrospective analysis of firearm injuries and deaths recorded by forensic medical authority during the period between January 2016 and October 2019. This research documented that firearm injuries increase gradually in years 2016 and 2017. Firearm injuries were 23 cases $(23 \%)$ in year 2016 while in year 2018, firearm injuries were 27 cases $(27 \%)$ and in year 2019, firearm injuries were 28 cases $(28 \%)$. These findings disagree with those obtained by other researchers who recorded firearm injured cases that ranged from 37 cases $(13.7 \%)$ to 53 cases $(19.8 \%)$ per year, with the largest number occurring in year 2007 (53 cases; 19.8\%), followed by year 2010 (50 cases; 18.7\%), then year 2005 (46 cases; 17.2\%), then year 2009 (42 cases; $15.7 \%$ ), then year 2006 (40 cases; $14.9 \%$ ), and finally year 2008 (37 cases; $13.8 \%) .{ }^{(4)} \mathrm{A}$ similar study showed that the number of firearm injuries was high in year $2011(23.7 \%)$ and gradually decreased to $(13.9 \%)$ in year2013. An increase was 
noticed in year $2014(22.8 \%)$ and this was followed by a decrease to the least percentage documented through the research period in year $2016(4.7 \%)$ (Enas M. Morsi Mohammed and Amro A. Saleh, 2019)

The present study showed that firearm injuries are more common in males $(94.1 \%$ of cases) in year 2016 but 5, 9\% of cases were females. In year $2017,87.5 \%$ of cases were males but $12.5 \%$ of cases were females. In year 2018, 93\% of cases were males but $6.7 \%$ of cases were females. In year $2019,72.2 \%$ of cases were males but $27.8 \%$ of cases were females. Similar studies in Saudi Arabia endorsement that the majority of firearm injuries $(n=98$, $96.1 \%$ ) of the patients were males and only 4 cases were females. (Anthony M, Nasser AAIAqil1, Nawaf A AlOkeil, et al., 2019).

In agreement with the results obtained in this study other researches, proved that 55 cases of firearm injuries $(20.5 \%)$ were males and 2 cases $(0.7 \%)$ were females (Abeer Mohamed Hagras a and Magdy A.A. Kharoshah, 2012) This can be explained by males are unable to control their feelings of rage in their everyday activities, where violence is ensured. Males are more than females since they are required to keep up honour of the family and any risk to it that can prompt brutality, while females are in general stay inside. Females are more uncertain to take part in battles that could prompt homicide (AbdelHady H, Abdel-Moneim $M$ and AbdelAal M., 2008).

Rural areas were the main place for firearm injuries. In 2016, 14 cases $(63.64 \%)$ were from rural areas while 8 cases $(36.36 \%)$ were from urban. In 2017 , 17 cases $(73.91 \%)$ were from rural areas but 6 cases $(26.09 \%)$ were from urban. In 2018, 21 cases $(77.7 \%)$ came from rural areas and 6 cases $(22.23 \%)$ were from urban. In 2019, 20 cases $(71.42 \%)$ were from rural areas but 8 cases $(28.58 \%)$ were from urban agreement with our study a study was during the period between
January 2005 and December 2010 in the Suez Canal Area, 150 (56.0\%) out of 268 cases of firearm crimes occurred in rural areas, while 118 cases $(44.0 \%)$ occurred in urban areas. Also, a study carried out in ElFayoum Governorate to study firearm fatalities found that $73.2 \%$ of firearm crimes occurred in rural areas while $26.8 \%$ occurred in urban areas. In addition, A study was in Menoufiya University Hospital on firearm injuries reported that such injuries were more common in rural areas than in urban areas $(72.41 \%$ and $27.59 \%$, respectively). It can be said that firearm crimes are more common in rural areas (Kır MZ, Ketenci HC, Basbulut AZ and Ozsoy S., 2012). This may be because farmers always keep weapons to protect their lands and rural areas have less legal control than urban areas (Omoke NI., 2017).

The current study revealed that, firearm injuries are more common in age group between (20-40) years. They were 60 males $(86.96 \%)$ and 9 females $(13.04 \%)$. Our results are similar to those reported in El-Monofia Governorate, Egypt, during the year 2000, where the highest incidence occurred in the age group 20-30 years, and the majority of victims were males (88.6\%).A retrospective study recorded all firearm fatalities in El-Fayoum Governorate during the 7 year period from 2000 to 2006 . The study reported that the most affected age group in the studied victims was the third decade $(29.6 \%)$, followed by the fourth decade $(25.4 \%)$. The least affected age group was above the sixth decade (1.4\%) (Abdel-Hady H, Abdel-Moneim $\mathrm{M}$ and Abdel-Aal M., 2008).

Moreover, other study done in Assiut Governorate documented that the elevated incidence of firearm injuries and fatalities occurred in the age group 21-30 years $(31.3 \%)$, followed by the age group 31-40 years $(25.5 \%)$. Most victims were males $(86.3 \%){ }^{(12)}{ }^{(14)}$ The results of the current study differ from that of a study done in 
Qena Governorate that outlined the pattern of firearm injuries ${ }^{(13)}$. There, the rate of incidence was in the age group 3040 years $(49.5 \%)$, followed by the age group $40-50$ years $(25.2 \%)$. No victims were younger than 20 years, and most of the victims were male $(94.2 \%)$ ). Our results agree with those of the study in Pakistan that collected data about firearm injuries and fatalities in the years 2007 and 2008. It was shown that almost all age groups were represented, with the majority of victims being adults and middle-aged persons (GamalEldin A, Ahmed T , El-Ghamry H., 2008).

The age group20-40years are the most age group in everyday activities and work, where violence and battles are occurred (Kır MZ, Ketenci HC, Basbulut AZ and Ozsoy S., 2012).

In year 2016 there was only one case $(4.50 \%)$ of firearm injuries in head and neck, 15 cases (68.18) of firearm injuries in limbs, 4 cases $(18.00 \%)$ in trunk and 2 cases (9.00) in more than on site in the same victim. In year 2017 there was 2 cases $(8.70 \%)$ in head and neck, 13cases (56.50) in limbs, 2 cases(13.50\%) in trunk and 5 cases(21.30) in more than on site in the same victim. in year 2018 there were 3 cases $(11.10 \%)$ of firearm injuries in head and neck, 14 cases (51.90) in limbs,3 cases $(11.10 \%)$ in trunk and 7 cases $(25.90)$ in more than on site in the same victim. in year 2019 there was 7 firearm injured cases $(25.00 \%)$ in head and neck, 14 cases (50.00) in limbs, 3 cases $(7.30 \%)$ in trunk and 5 cases (17.80) in more than on site in the same victim. In contrast to our results, a study in Qena Governorate in Egypt reported that the chest and the abdomen were the most common sites of wounds, representing $23.3 \%$ and $22.3 \%$, respectively, another study in El-Fayoum Governorate, recorded that, the most common site of firearm injuries was the chest followed by the abdomen GamalEldin A, Ahmed T, El-Ghamry H and Ghaleb S., 2008), (Kir MZ, Ketenci HC, Basbulut AZ and Ozsoy S., 2012)
This study revealed that most of firearm injured cases were accidental in year 2016. While in years 2017, 2018, 2019 cases were mainly homicidal. This agrees with the study done by Hagras and Kharoshah (2012) who reported that, the most common manner of firearm injuries was homicide. In addition, a study in Menoufiya by Maklad et al. (2004) reported homicide in $71 \%$ and suicide in $29 \%$ of cases of firearm injuries. Contrary to our results, Denmark and New Zealand studies showed that, suicides accounted for the vast majority of firearm fatalities.(Enas M. Morsi Mohammed and Amro A. Saleh, 2019), (Omoke NI., 2017), (Odhiambo WA, Guthua SW, Chindia ML and Macigo FG., 2008).

\section{RECOMMENDATION}

More studies and analysis of firearms injuries

\section{REFERENCES}

Abdel-Hady H, Abdel-Moneim $M$ and Abdel-Aal M. (2008): Firearm injuries and fatalities. A preliminary study report in Assiut Governorate, Egypt in year Zagazig J Forensic Med Toxicol, 6(1):97-118.

Abeer Mohamed Hagras a and Magdy A.A. Kharoshah (2012): Medicolegal evaluation of firearm injuries during the period from 2005 to 2010 in the Suez Canal Area, Egypt: A retrospective study, Egyptian Journal of Forensic Science, 2, 1- 10.

Aboelyazid Foud, Ahmed Mousa, Ossama Zakaria and Hazem Zakria(2019): Medicolegal and clinical aspects of peripheral vascular injuries: A retrospective study, The Egyptian Journal of forensic science and applied Toxicology, 19(1), p145161.

Al Madni and M. Kharosha, A. (2008): Shotar Firearm fatalities in Dammam, Saudi Arabia Med Sci Law, 48 (3) pp. 237-240. 
Anthony M, Nasser AAlAqil1, Nawaf A AlOkeil, Shatha A AlGhaleb2, et al. (2019): Firearm injuries in rural Saudi Arabia: incidence, patterns, management, and cost, Egyptian Journal of Forensic Sciences 9:4.

Enas M. Morsi Mohammed and Amro A. Saleh (2019): Forensic Analysis of Firearm Injuries in Fayoum Governorate in the Period from 2011 to 2016, Ain Shams Journal of Forensic Medicine and Clinical Toxicology 33: 1-7

GamalEldin A, Ahmed T, El-Ghamry $H$ and Ghaleb S,(2008): Study of cases of firearms fatalities in El-Fayoum Governorate during 7 years period (2000-2006) retrospective study. BeniSueifUniv Med J;1(1):70-92.

\section{H. Abdel-Hady, M. Abdel-Moneim} and M. Abdel-Aal (2012): Firearm injuries and fatalities. A preliminary study report in Assiut Governorate, Egypt in year. Egyptian Journal of Forensic Sciences 2, 1-1.

Humayun M, Khan D, Zaman F, Khan J, Khan O, Parveen Z, et al. (2009): Analysis of homicidal deaths in district Di Khan: an autopsy study. J Ayub Med Coll Abbottabad; 21(1).

Iflazoglu N, Ureyen O, Oner OZ, Tusat $M$ and Akcal MA. (2015): Complications and risk factors for mortality in penetrating abdominal firearm injuries: analysis of 120 cases. Int J ClinExp Med.;8(4):6154-62.

Karaca MA, Kartal ND, Erbil B, Öztürk E, Kunt MM, Şahin TT, et al. (2015): Evaluation of gunshot wounds in the emergency department. UlusTravmaAcilCerrahiDerg; 21(4):248- 55.

KasımTurgut, Ali Gür,; TanerGüven, and

HakanOğuztürk(2019)
:Evaluation of Factors Related to Mortality Caused by Firearm Injury: A Retrospective Analysis from Malatya, Turkey, Arch Iran Med. 22(2):80-84.

Kır MZ, Ketenci HC, Basbulut AZ and Ozsoy S. (2012): Evaluation of firearm-related deaths in Erzurum. J For Med. 2012; 1:27-37.

Lustenberger T, Inaba K, Schnüriger B, Barmparas G, Eberle BM, Lam L, et al. (2011): Gunshot injuries in the elderly. Patterns and outcomes. A national trauma data bank analysis. World J Surg. 35(3):528-34.

M. Humayun, D. Khan, F. Zaman, J. Kh an, O. Khan, Z. Parveen, etal (2009): .Analysis of homicidal deaths in district Di Khan: an autopsy study $\mathbf{J}$ Ayub Med Coll Abbottabad, 21 (1):22-23.

Maklad A, El-Mehy L and Mohdy M (2004): A medico-legal study of firearm injuries in El-Monofia Governorate. Ain Shams J Forensic Med ClinToxicol ;2:1-19.

Odhiambo WA, Guthua SW, Chindia ML and Macigo FG. (2008): Pattern and clinical characteristics of firearm injuries. East Afr Med J; 85(3):107-12.

Omoke NI. (2017): Firearm Injuries Received in Emergency Room of a Nigerian Teaching Hospital: Analysis of Pattern, Morbidity and Mortality. Niger J ClinPract. 2017; 20(5):587594.

Saly Y Abdel- Hameed, Ahmed K Ibrahim, Hayam $\mathrm{Z}$ thabet and Aml A Mohamed (2017): Pattern of traumatic injuries and mortality in tertiart trauma center, Assiut University Hospitals (from 2005 to 2012), The Egyptian Journal of forensic science and applied Toxicology,17(1): p 89-108. 


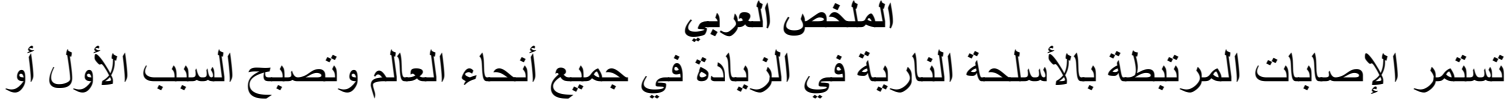

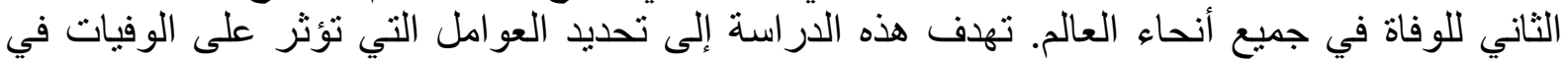

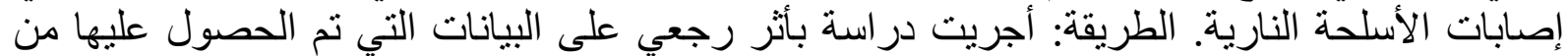
100 مريض مصاب بسلاح ناري تم تسجيلهم لدى هيئة الطب الثرئة

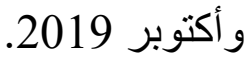

و أظهر هذا البحث زيادة طفيفة في إصابات الأسلحة النارية. في عامي 2016 و 2018 و 2017، سجلوا 22 الإنة 20

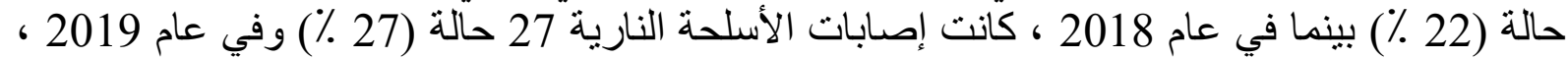

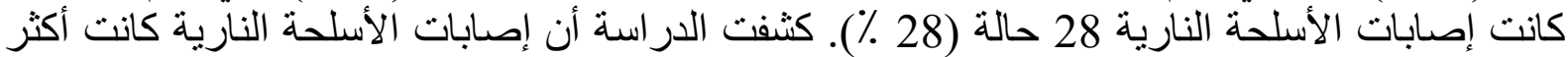

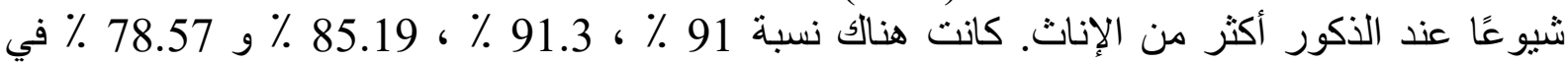

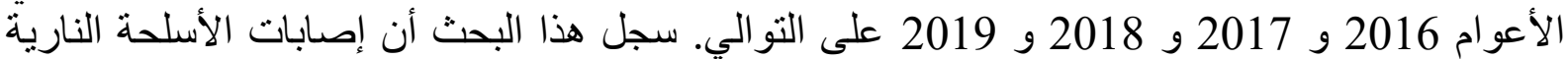

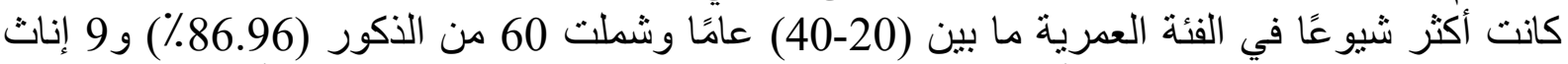

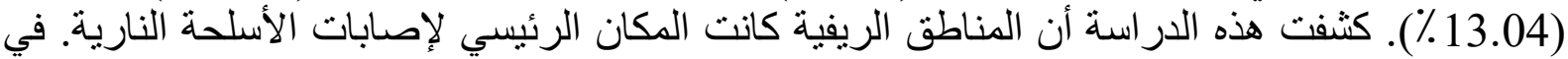

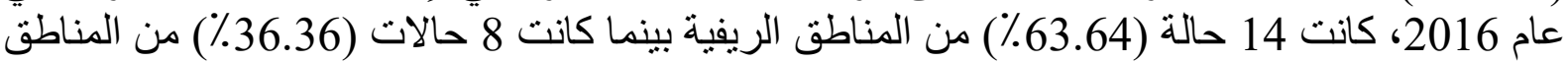
الحضرية. في عام 2017، كانت 17 حالة (73.91\%) من الريف ولكن 6 حالات (26.08\%) كانت في

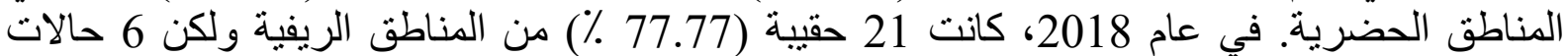

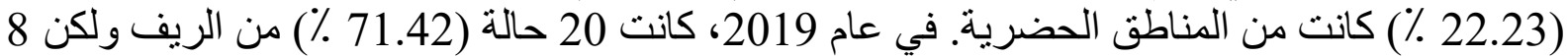

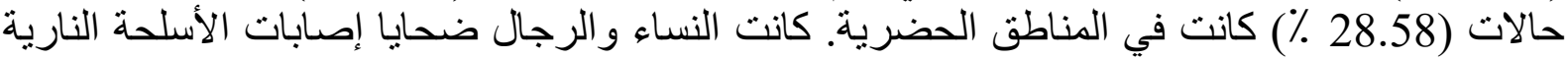

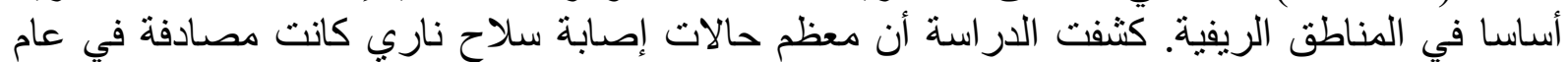
2016 بينما في عام 2017، 2018 ، 2019 كانت حالات إصابة سلاح ناري بسبب المناب المناز عات. 